\title{
Magnetotelluric soundings across the Taubaté Basin, Southeast Brazil
}

\author{
Antonio L. Padilha, Ícaro Vitorello, and Paula M. A. Brito \\ Instituto Nacional de Pesquisas Espaciais - INPE, C.P. 515, 12201-970 São José dos Campos, Brazil
}

(Received December 19, 2000; Revised November 30, 2001; Accepted December 7, 2001)

\begin{abstract}
Thirteen magnetotelluric (MT) soundings were carried out in Neoproterozoic crystalline terrains and Tertiary sediments of the Taubate basin, southeastern Brazil. The soundings were deployed in a cross-strike profile bisecting the basin along one of its thickest sub-basins and extending over mountain plateaus to the southeast and the northwest. Occurrences of numerous alkaline plugs and aligned tectonic grabens in the region are records of intense Mesozoic-Cenozoic tectonic activity. MT analysis techniques were used to evaluate data quality, infer strike direction, and correct for near-surface distortion. As the studied area is located only some tens of kilometers away from the Atlantic Ocean and in one of the most densely populated regions of the country, the data are severely distorted by industrial interference and the coast effect. Because of such effects, the data are modelled using a 2D inversion scheme within periods shorter than $0.1 \mathrm{~s}$ for the Taubate Basin sites and shorter than 1-10 s for the offbasin sites, the latter depending on the distance of the site from the coast. The main result observed in the modelling is the identification of a conducting zone below $10 \mathrm{~km}$ depths beneath the region. There is poor resolution in the data of structures below this conductor, which is also not imaged beneath the basin. Studies carried out in different tectonic regions of the world have also reported conductive layers at about the same depth but in the studied area it is impossible to reach any conclusion about the total conductance of the layer with the available MT data.
\end{abstract}

\section{Introduction}

The southeastern region of Brazil is characterized by a Precambrian crystalline basement that shows brittle and sometimes ductile deformation in a terrain extensively recycled during the Neoproterozoic Braziliano-Pan African Orogeny and marked by widely extended Mesozoic-Cenozoic events. Basement outcrops are composed of mylonite gneiss, blastomylonites, mylonites, banded gneiss, granitic gneiss, schists, quartzites, amphibolites, granites, pegmatites, aplites, and migmatites that were transported laterally and vertically by ubiquitous transpressive fault systems.

The basement also records activity from the MesozoicCenozoic period, including alkaline magmatism, uplift and denudation and also brittle crustal deformation represented by deep cataclastic zones associated with reactivated subvertical transcurrent faults, aligned long tectonic depressions, and neotectonic features (Fig. 1). The alkaline intrusions are geographically dispersed in a region south of $22^{\circ} \mathrm{S}$ latitude and inferences have been made about an apparent alignment with inland prolongation of oceanic fractured zones (e.g., Sadowski and Dias Neto, 1981). Alternatively, the alignment of these intrusions has been suggested to have recorded the passage of continental lithosphere over the Trindade mantle plume (Thompson et al., 1998).

The current geomorphological relief, resulting from uplift followed by denudation, displays a three step staircase in a NW cross-section tilted backwards to the continent and comprised, in this direction, by the coastline platform and

Copy right (C) The Society of Geomagnetism and Earth, Planetary and Space Sciences (SGEPSS); The Seismological Society of Japan; The Volcanological Society of Japan; The Geodetic Society of Japan; The Japanese Society for Planetary Sciences. the Serra do Mar and Serra da Mantiqueira plateaus. Located along the western edge of the Serra do Mar plateau, the aligned tectonic depressions are filled with Tertiary continental sediments, constituting a system of half-grabens tilted to the NNW. The following basins are found in an arcuate distribution in a sequence from the south to the northeast, roughly parallel to the Precambrian tectonic features and the coast line (Fig. 1): Curitiba (1), Cananéia (2), Pariquera-Açu (3), Sete Barras (4), São Paulo (5), Taubaté (6), Resende (7), Volta Redonda (8), Guanabara (not shown), and Itaboraí (9).

Available geoelectrical studies in the area include a previous magnetotelluric (MT) survey carried out only within the Taubaté Basin (number 6 in Fig. 1), the major elongated half-graben. The survey was restricted to the period range of 0.2 to $100 \mathrm{~s}$ (Padilha et al., 1991). As a result of an integrated interpretation of these MT data and other available geophysical data, the authors claimed that tectonism related to the formation of this basin did not leave any thermal anomaly at crustal depths perceivable by the geophysical methods applied. In a further study, Padilha and Vitorello (1992) have analyzed hundreds of audiomagnetotelluric (AMT) soundings (frequencies of 8 to $4500 \mathrm{~Hz}$ ) to determine the superficial geoelectric features of the Volta Redonda, Resende, Sete Barras and Taubaté basins. More recently, Figueiredo (1997) conducted a $250 \mathrm{~km}$ long MT profile crossing both the Serra do Mar and Serra da Mantiqueira plateaus approximately $300 \mathrm{~km}$ northeast of the present study (profile B-B' in Fig. 1). Those data showed lateral variations of conductivity in the upper crust, limited by a conductor at $10 \mathrm{~km}$ depth with a conductance of $100 \mathrm{~S}$ along the entire profile.

Other available geophysical data include seismic and 


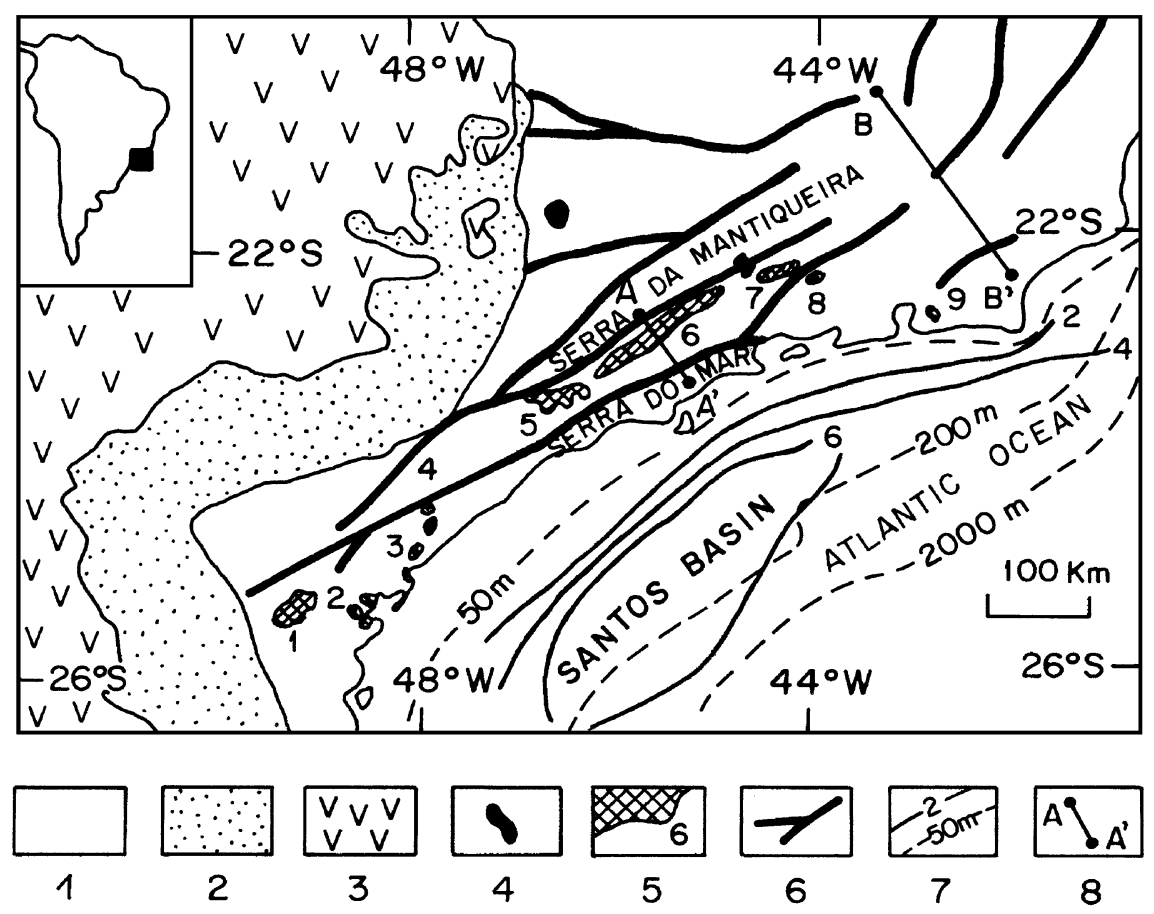

Fig. 1. Schematic geology of southeastern Brazil showing the studied region with the location of the MT profiles discussed in the paper. 1. Precambrian crystalline complex; 2. Paleozoic sediments (Paraná basin); 3. Mesozoic basaltic volcanics (Paraná basin); 4. Mesozoic-Cenozoic alkaline intrusions; 5. Cenozoic sediments-filled tectonic depressions (1. Curitiba; 2. Cananéia; 3. Pariquera-Açu; 4. Sete Barras; 5. São Paulo; 6. Taubaté; 7. Resende; 8. Volta Redonda; 9. Itaboraí; not shown Guanabara); 6. large subvertical transcurrent faults with associated cataclastic zones; 7. Atlantic ocean bathymetry (dashed lines) and Santos Basin thickness in kilometers (solid lines); 8. MT profile.

gravity surveys at the Taubaté Basin, which confirmed many of its inferred internal features (presence of structural highs forming several sub-basins along its main axis, asymmetry between lateral borders, and reversion of asymmetry polarity at some sub-basin boundaries) and allowed estimation of its maximum thickness of $850 \mathrm{~m}$ at the Tremembé sub-basin (Marques, 1990; Ramos et al., 1990).

The objective of the present study is to complement previous geoelectrical studies by deploying MT soundings in a NW-SE profile that cross the orthogonal basement tectonic fabric and the deep transcurrent faults responsible for the half-graben depressions (profile A-A' in Fig. 1). Therefore, the new data bring information from outside the boundaries of the basin and of the possible screening effects caused by the conductive thick sedimentary package that could have limited the resolution of the previous results of Padilha et al. (1991).

\section{Geological and Geophysical Context}

The Precambrian crystalline complex of southeastern Brazil is composed of lithologies of very distinct ages, composition, metamorphism, and origin of crustal level. They range in age from the Archean to the Neoproterozoic, in silica content from mafics to felsics, in metamorphic grade from greenschist to high grade granulite facies and have been transported from the mid- and lower-crust. Presently they are distributed along NE-SW tectonic structures related to a complex history of subduction and back-arc processes, orogeny and collapse from continental collision, and respective subsidence, uplift, denudation, and magmatism.

The most conspicuous feature in the study area is the elon- gated Taubaté Basin, with a width of up to $20 \mathrm{~km}$ and a length of about $170 \mathrm{~km}$, aligned with the NE-SW tectonic strike of the basement (Fig. 2). The basin is characterized by an asymmetry between its lateral borders (a half-graben) and the occurrence of small faults cutting the sediments. One of its margins, which generally presents larger subsidence, is marked by contact faults between the crystalline and sedimentary rocks, whereas the other margin exhibits a transgression of sediments over the basement. The basin is filled with Upper Eocene-Oligocene sequences (named the Taubate Group) that include basal pelitic material of lacustrine facies that grades to the top and laterally to fluvial facies of sandy nature. In some parts of the basin a third stratigraphic unit of fanglomeratic facies is also present. Extensive AMT soundings have characterized the sedimentary pile with a mean resistivity of 5 ohm.m (Padilha and Vitorello, 1992).

Based on the resemblance of the structural framework, similarity between sedimentary facies, and synchronism of evolution, the geologic formation of these depressions is considered to be connected with a common tectonic event during the Cenozoic (Almeida, 1976; Hasui et al., 1978). However, there are controversies related to the proposed regional evolutionary models. Initial theories linked the formation of the system to the late stages of South Atlantic opening. Consequently, Almeida (1976) called this region the "Serra do Mar Rift System," ascribing its development to opposite vertical movements between the Santos Basin (see location in Fig. 1) in the continental margin to the east, and the inland continental region to the west. Based on the same general idea, several other models have been sug- 


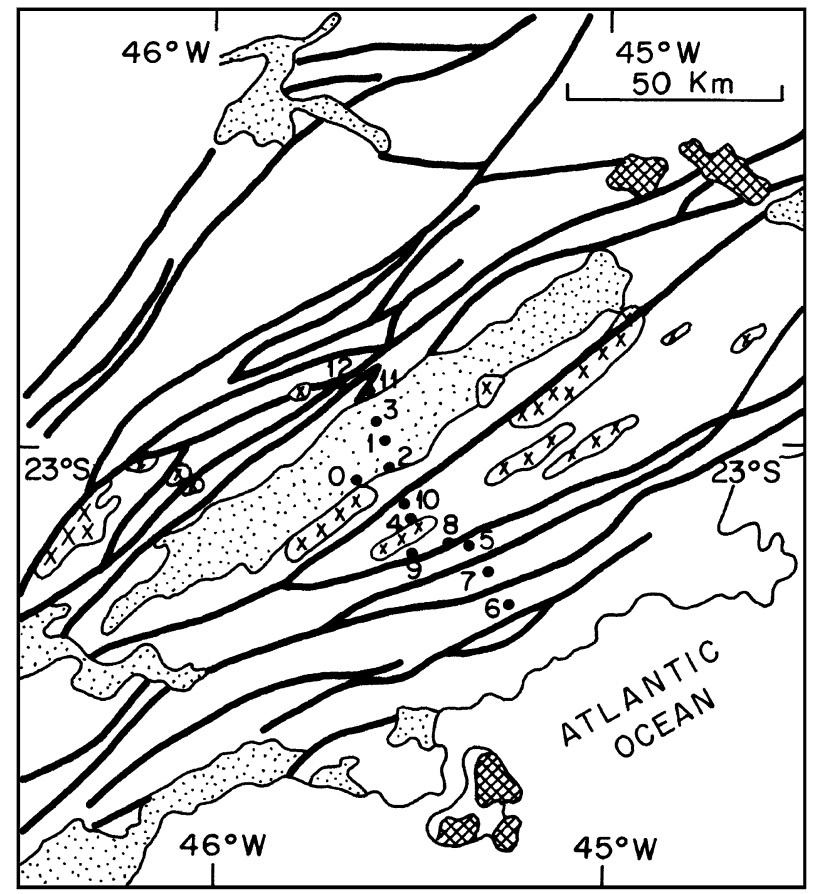

1

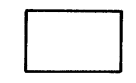

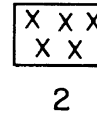

2

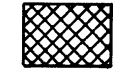

3

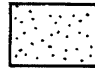

4

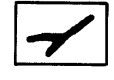

5

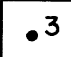

6
Fig. 2. Abridged geologic map of the area around the Taubate Basin with the location of the MT stations (partially modified from RADAMBRASIL, 1983). 1. Precambrian crystalline complex reworked in the Neoproterozoic (Braziliano Cycle); 2. Late Proterozoic syntectonic granitoid; 3. Mesozoic-Cenozoic alkaline rocks; 4. Cenozoic sedimentary cover; 5 . Transcurrent faults; 6 . MT site.

gested in the light of lithospheric distension tectonics (Hasui et al., 1978; Asmus and Ferrari, 1978; Riccomini, 1989). Such models imply upwelling of the asthenosphere to the base of the crust or the outflow of a very ductile (low viscosity) underlying lower crust. Alternatively, Zalán (1986) suggested that these half-grabens resulted from strike-slip displacements between brittle crustal blocks of the Neoproterozoic mobile zone, reactivated during the MesozoicCenozoic period. However, scarcity of corroborative geophysical data has hindered a better understanding of the geodynamic processes accountable for the observed geological features. Seismic activity of low intensity occurs with a scattered regional distribution, being more frequent close to the Santos Basin in the continental platform (Berrocal et al., 1984). Also, heat flow measurements in the Serra do Mar and Serra da Mantiqueira mountain plateaus give typical values of a Proterozoic terrain distant from a cratonic margin (around $60 \mathrm{~mW} / \mathrm{m}^{2}$; Padilha et al., 1991).

Diabase intrusions in the form of dikes and sills appear to be contemporaneous with the Upper Jurassic-Lower Cretaceous volcanics of the large intracratonic Paraná basin, located to the west of the study area, and the magmatism of the South America-Africa break up, to the east. Upper Cretaceous-Lower Tertiary alkaline volcanic events and the prominent and large NE-SW trending transcurrent faults are coincident with the drift phase of the South Atlantic plate
(Deckart et al., 1998). AMT soundings have shown that the crystalline rocks can be represented by a superficial thin layer of relatively low resistivity (a few tens of meters thick zone of about 30 ohm.m) over a thick and extremely resistive lower layer (about 10,000 ohm.m).

\section{MT Data Acquisition and Processing}

The MT method uses simultaneous measurements of natural time variations in the Earth's magnetic field components, $H_{x}, H_{y}$, and $H_{z}$, and the orthogonal horizontal components of the induced electric field, $E_{x}$ and $E_{y}$, to obtain the distribution of the electric conductivity in the Earth's interior. In this study, the five electromagnetic components were recorded at thirteen stations along a $65 \mathrm{~km}$ profile, in the NW-SE direction, roughly perpendicular to the main structural direction of the crystalline basement and the main axis of the Taubaté Basin (Fig. 2). A commercial singlestation MT system (GMS05, METRONIX Gmbh) was used in a coordinate system with one of the horizontal axis normally aligned with the magnetic meridian. The telluric field variations were measured with typically $100 \mathrm{~m}$ dipoles, in a cross-configuration, with non-polarizable cadmiumcadmium chloride electrodes whereas the magnetic fields were measured with induction coils for the two horizontal and the vertical components. At most sites the period range was $0.00080-2048 \mathrm{~s}$ and recording times were typically at least 24 hours. The complex-valued MT tensor elements and geomagnetic transfer functions were computed using the code of Egbert and Booker (1986).

\subsection{Data quality}

As the studied area is located in a major industrial zone in one of the most densely populated regions of Brazil, careful site selection was required to minimize cultural noise caused by industries, power lines and local energy consumers. Also a DC electrified railway crosses the northern part of our profile, but fortunately it only operates during the day. As a consequence, data quality is strongly conditioned by site location. This is demonstrated in Fig. 3, where MT results from two different sites are shown.

Site 1 in Fig. 3 is representative of stations close to the center of the Taubaté Basin. Apart from larger error bars at the longest periods, attributed to the limited recording time at these periods and the lack of geomagnetic activity during fieldwork, the data appear to be of good quality. Also, the parallel and perpendicular apparent resistivities and phases are identical to about $100 \mathrm{~s}$ (when $Z_{y x}$ phase is translated to the first quadrant), a possible indication of onedimensional (1D) structure to great depths (at least the entire crust). The 'Rho+' code (Parker and Booker, 1996) was used to assess the validity of a 1D model at each orientation. The best fitting 1D model was obtained, and the maximum permissible variation of each apparent resistivity and phase data from their predicted value were calculated considering a confidence level of $95 \%$. It was observed that the apparent resistivity and phase data remain within the limits of a 1D model, with little mismatch between the two data sets.

Site 6 in Fig. 3 is a typical example of soundings carried out directly over the exposed Precambrian rocks. Data quality is apparently less satisfactory because these sites seem to be more severely disturbed by cultural noise that spreads 

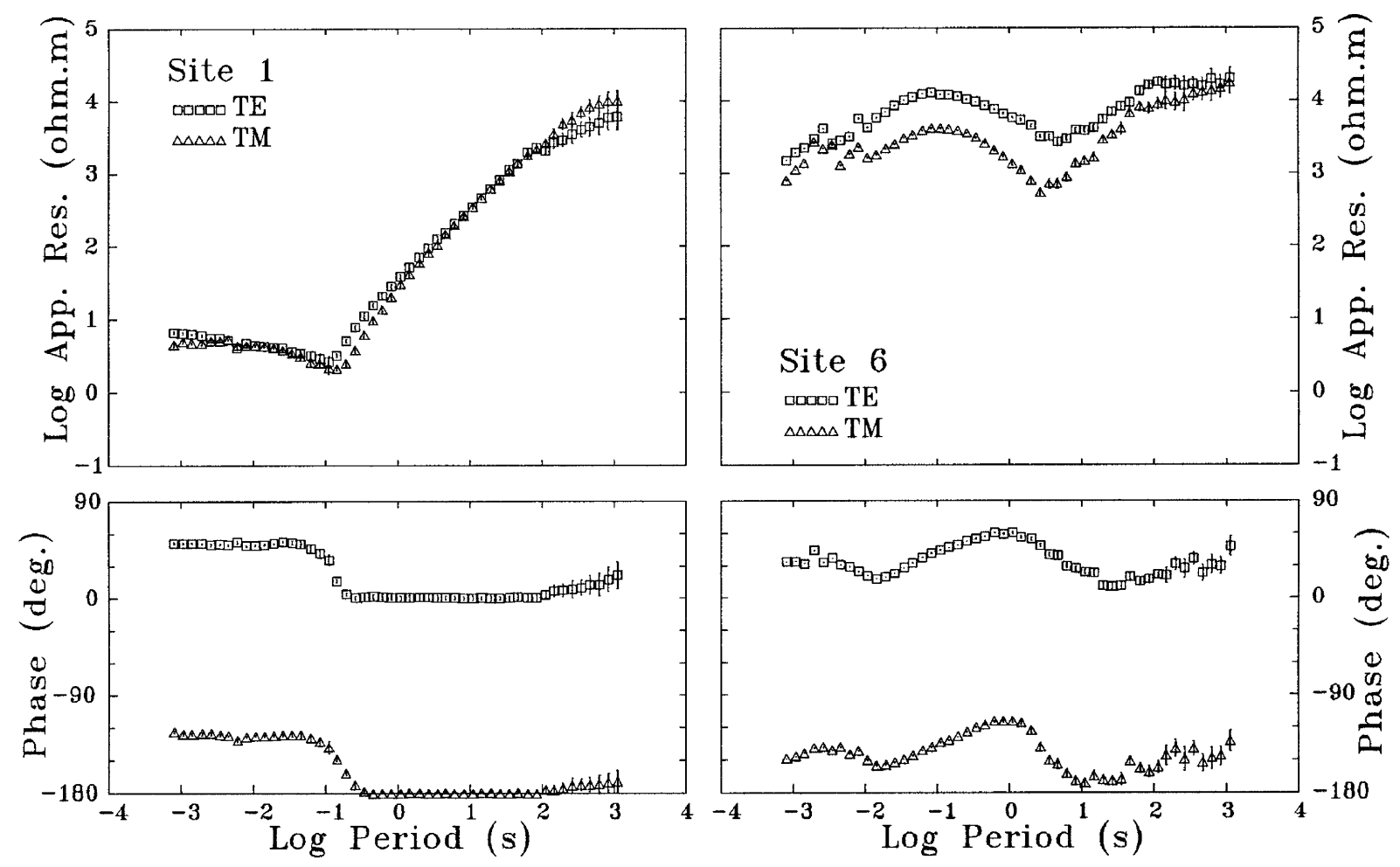

Fig. 3. Typical MT results from soundings over the sediments of the Taubaté Basin (site 1) and directly over the crystalline rocks outside the basin (site 6). Apparent resistivities and phases are shown with error bars representing one standard deviation.

over large distances in resistive terrains. At some sites, especially close to the electrified railway, it was not possible to get good quality data at periods greater than $100 \mathrm{~s}$. Also, due to the weakness of the vertical magnetic field, the geomagnetic transfer functions are generally much more affected by the high noise level than the magnetotelluric responses. Consequently, these transfer function estimates are not used in our analyses. Except for static shift problems (to be discussed later), the MT responses from locations distant from the basin border are roughly 1D from the shortest period up to periods around $100 \mathrm{~s}$. At longer periods, the two sets of information which describes TE and TM modes seem to diverge.

The apparent 1D behavior of all soundings at most of the sampled frequencies is illustrated in Fig. 4. The phase data from all sites are shown, with the soundings on the exposed Precambrian rocks separated from the soundings on the Cenozoic sediments. Note the similarity of phase response from all sites in the resistive terrain (Fig. 4(a)), suggestive of a region in which the conductivity varies with depth alone. On the basin (Fig. 4(b)), the phases are different in the interval $0.01-0.1 \mathrm{~s}$, indicative of different thickness of the sedimentary package under each site. A qualitative analysis of the off-basin data also shows that the presence of a conducting layer in the deep crust is indicated by phase values larger than $45^{\circ}$ at periods longer than $0.1 \mathrm{~s}$. On the basin, this feature is not readily apparent in the curves. In this case, the sedimentary sequence seems to mask the features of deep layers in the crust.

However, the MT responses at the four sites in the Taubaté Basin are characterized by apparent resistivity curves with

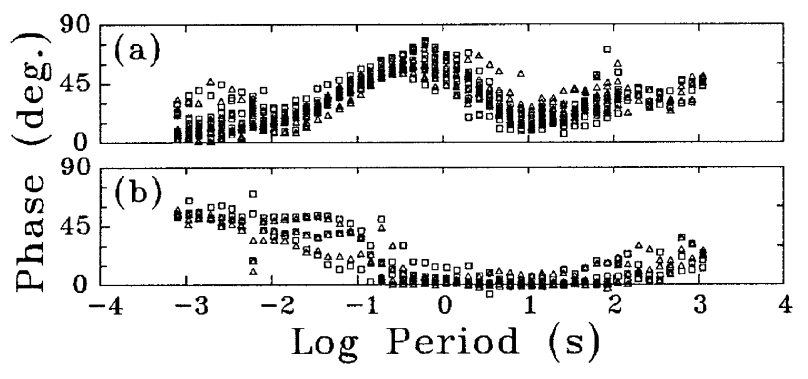

Fig. 4. Phase data from all sites. Upper graph shows soundings located on exposed Precambrian rocks; lower graph shows soundings on Cenozoic sediments.

inclination near $45^{\circ}$ (as illustrated at site 1 in Fig. 3) and phase values close to zero (as can be observed at every site in Fig. 4(b)) for over 2 decades at periods roughly greater than $0.1 \mathrm{~s}$. Such results are usually taken as indicative of severe industrial interference on MT soundings (e.g., Qian and Pedersen, 1991). In fact, the present situation seems to be similar to that observed in CSAMT data acquired for a conducting zone over a resistive one (see for instance the Boerner et al.'s (1993) work at Buchan's Mine in Newfoundland). At the higher frequencies sensing the upper conducting zone, the CSAMT bipole source is sufficiently distant in an electromagnetic (EM) sense for the data to be far-field and thus be interpreted as plane-wave MT methods. However, as soon as the frequencies are sufficiently low for the basement to be sensed, the source instantly becomes close in an inductive sense and the responses are near-field, 
so that they only provide information about the geometry of the source.

For the Taubaté Basin sites, the industrial interference is attenuated at periods shorter than $0.1 \mathrm{~s}$ by the sediments within the basin. As soon as the period increases to $0.1 \mathrm{~s}$ and above, the industrial noise carried by EM waves in the basement is sensed. The data can be used to get sedimentary thicknesses within the basin, but cannot be used for any deeper structures sensed at periods beyond $0.1 \mathrm{~s}$. This conclusion is supported by the results of AMT soundings carried out within the basin (Padilha and Vitorello, 1992), which had indicated a maximum conductance of $200 \mathrm{~S}$ for the sedimentary package (resistivity around $5 \mathrm{ohm} . \mathrm{m}$ and thickness less than $1 \mathrm{~km}$ ). Such results succesfully match the ones available from boreholes, DC vertical soundings, seismic, and gravity surveys (DAEE, 1977; Marques, 1990; Ramos et al., 1990).

\subsection{Strike direction}

Use of conventional Swift's method (Swift, 1967) to calculate strike angles has shown variable results, an indication that the data set are subject to near-surface 3D distortion. An analysis of the dimensionality of the impedance tensors is given in Fig. 5, which shows the results of Bahr's classification (Bahr, 1991) of the data set (maximum period limited to $100 \mathrm{~s}$ ). The graph shows an interpolation of Bahr's class numbers that represents the impedance tensors at each frequency. It is clearly observed that most of the data fit a $2 \mathrm{D}$ model distorted by local heterogeneities with only a galvanic response (classes 3 to 5). In general the local distortions are small at sites over the sediments of the Taubate Basin, indicative of little near-surface conducting heterogeneity. Significant intervals at short periods with data in classes 6 and 7 are only observed at sites 4 and 10 . At periods around $100 \mathrm{~s}$, the high class numbers are probably indicative of poor quality data as the signal-to-noise ratio becomes lower at longer periods (see Fig. 3).

The Groom-Bailey decomposition technique (Groom and Bailey, 1989) was applied to remove these galvanic distortions and to define a regional strike. Figure 6 shows uncon-

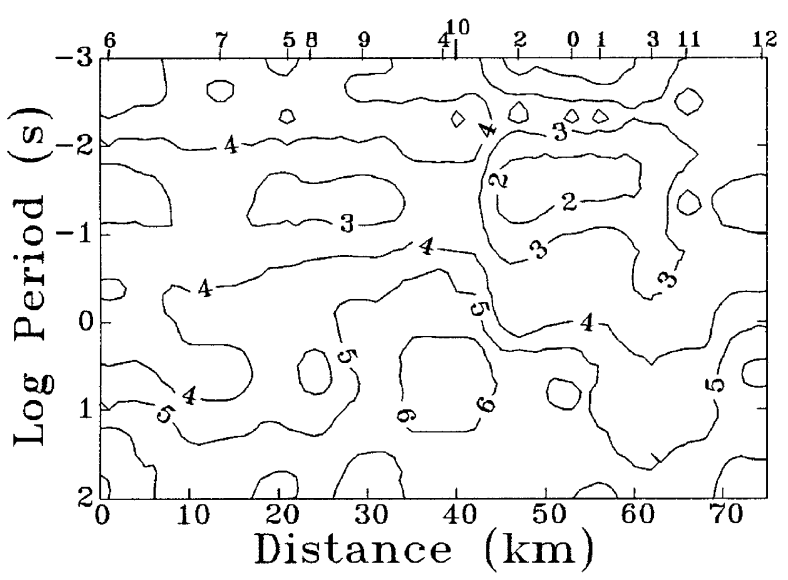

Fig. 5. Bahr's (1991) distortion class results. Site numbers are indicated at the top of the SE-NW section. Distance in the abscisse axis is defined by using site 6 as reference (horizontal position of site 6 has a small offset to enhance visualization). strained and constrained Groom-Bailey parameters at site 6, with associated residual errors. The errors indicate that the decomposition model at this station is inadequate at periods shorter than $0.01 \mathrm{~s}$. The strike angle that best fits all the sites over the entire period range is between $\mathrm{N} 20^{\circ} \mathrm{W}$ and $\mathrm{N} 40^{\circ} \mathrm{W}$. Since structural azimuths are ambiguous by $90^{\circ}$, the strike direction determined from the decomposition is consistent with the main geological trend $\left(\mathrm{N} 50^{\circ} \mathrm{E}\right.$; see Figs. 1 and 2$)$. Accordingly, distortion models were fit to the data with an assumed $\mathrm{N} 50^{\circ} \mathrm{E}$ strike direction.

\subsection{Static shift}

After correction for distortion, the latest unknown parameters are the absolute levels of the apparent resistivity curves at each site. Static shifts appear on MT data due to smallscale scatterers that distort the amplitudes of the recorded electric field, but do not affect the phase nor the magnetic field, resulting in a period-independent multiplicative shift of the apparent resistivity curve (e.g., Jones, 1988).

Apparent resistivity and phase responses for both TE and TM modes at a period of $0.1 \mathrm{~s}$ are shown in Fig. 7. This period gives a skin depth between 3 to $5 \mathrm{~km}$ in the resistive terrain and around $200 \mathrm{~m}$ in the sedimentary package and can be used to evaluate static distortions on the data (assuming that the dimensions of the heterogeneity are much smaller than the signal penetration into the surrounding rocks at such period). It can be seen that the phases in both polarizations are equal to one another at every location, whereas the apparent resistivities differ from each other at the sites over resistive terranes. These stations are found to have staticshifted data. As there is no regional trend in the shift, the distortion is likely caused by local effects. In contrast, the sedimentary basin stations do not show significant separation in their apparent resistivity estimates, which are also coincident with the results of other geoelectromagnetic measurements (including well logging). Thus, we conclude that these stations are relatively free of static shift effects.

Static shift distortion was compensated for in the 2D inversion. The approach used was to fit well the phase data at all stations and the apparent resistivities from the stations of the Taubate Basin, yet allowing a larger misfit to the apparent resistivity data of static-shifted stations (Wu et al., 1993). The small phase misfit ensures that the modelled apparent resistivity curves have the same shape as the observed curves, yet allows a frequency-independent shift. The model then reflects the regional trends of the apparent resistivity data without trying to fit local features caused by static shifts.

\subsection{Ocean effects}

It is expected that the EM data of this study are influenced by the conducting sea water of the adjacent Atlantic Ocean. To test the effects of the ocean on the MT data, we used a 2D finite element code (Wannamaker et al., 1987) to calculate the forward responses of different models, having the main features based on available information from geological and geophysical data (Fig. 8). The landward conductivity structure is a simplified version of the geoelectrical model derived by Brito (1998) for the same profile across the Taubate Basin, but without considering the ocean effect. It comprises the following layers:

1. the upper and lower crust are represented by blocks of 

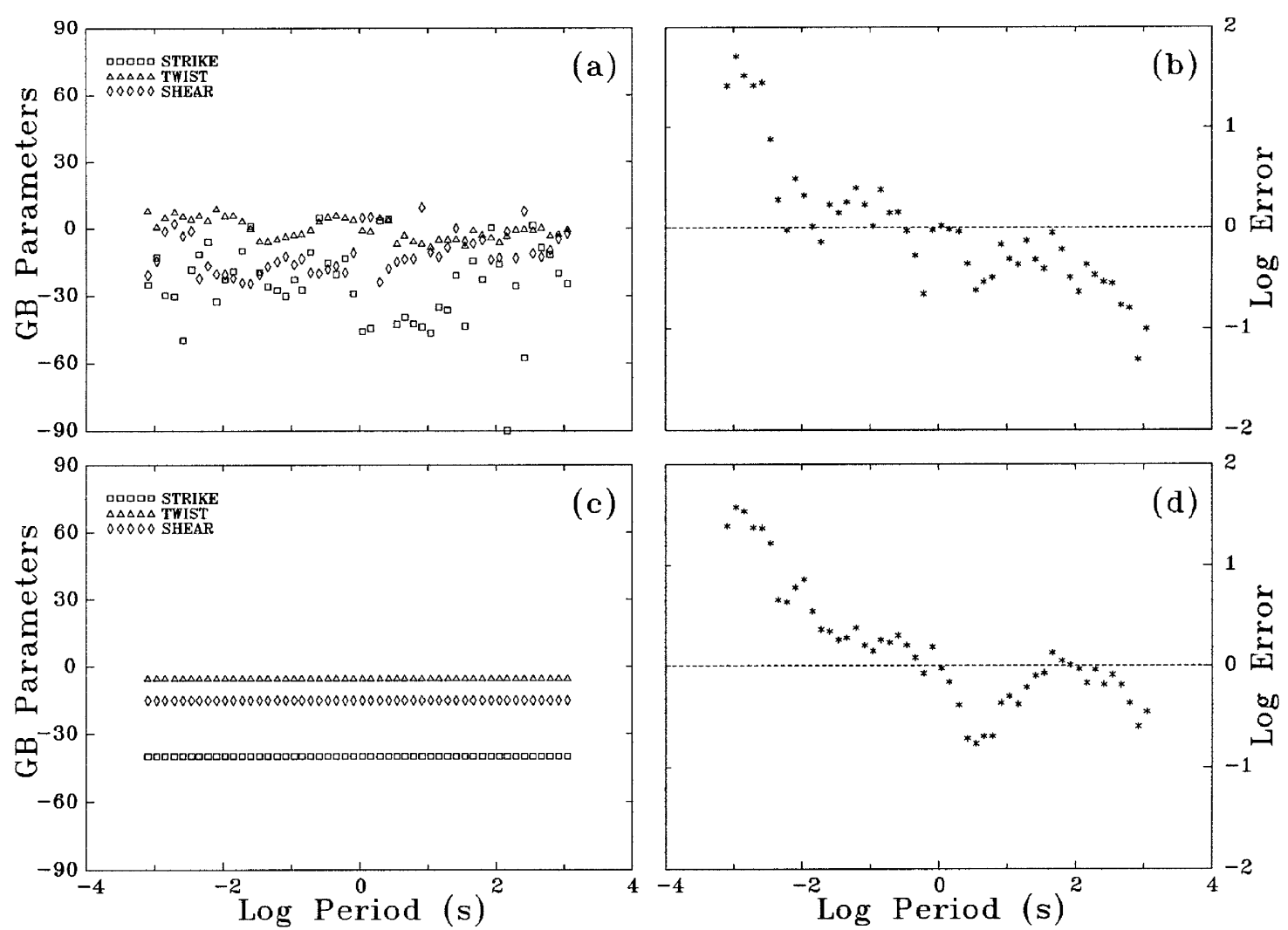

Fig. 6. Groom-Bailey decomposition for a 3D/2D model for the data from site 6. Upper graphs show (a) unconstrained strike, twist, and shear parameters and (b) associated residual error. Lower graphs show (c) constrained Groom-Bailey parameters and (d) residual error.

10,000 ohm.m, as observed in the 2D inversion of Brito's (1998) study;

2. a thin layer of $20 \mathrm{~m}$ and resistivity of $30 \mathrm{ohm} . \mathrm{m}$ (not shown in Fig. 8) is included at the top of the upper crustal resistivity block to account for the weathered overburden, as defined from AMT studies (Padilha and Vitorello, 1992); 3. an enhanced conductivity in the crust detected in Brito's (1998) study is represented by a layer of $20 \mathrm{~S}$ (thickness of $2 \mathrm{~km}$ and resistivity of $100 \mathrm{ohm} . \mathrm{m}$ ) at a depth of $10 \mathrm{~km}$.

The geoelectrical structure for the oceanward part was derived from available bathymetry and geological/geophysical data for the Santos Basin published by PETROBRAS's (Petróleo Brasileiro S.A.) researchers (e.g., Macedo, 1989; Pereira and Feijó, 1994). It includes the following layers:

1. the ocean is represented by a layer with a resistivity of $0.3 \mathrm{ohm} . \mathrm{m}$ and thicknesses reaching $2 \mathrm{~km}$ at a distance of $160 \mathrm{~km}$ from the coast;

2. the sediments in the Santos Basin are represented by a layer with a mean resistivity of $7 \mathrm{ohm} . \mathrm{m}$ and a maximum thickness of $5 \mathrm{~km}$ close to its depocenter (information inferred from induction logs and seismic lines);

3 . a resistive layer at the bottom of the sedimentary package, with a resistivity of $500 \mathrm{ohm} . \mathrm{m}$ and maximum thickness of $2 \mathrm{~km}$, represents salt units and volcanic rocks.

Different tests were performed using this basic model, checking the effects of including and excluding certain features, such as an asthenosphere at 100 or $200 \mathrm{~km}$, the ocean, and the presence or absence of the mid-crustal conductor. In particular, to test the effects of the ocean, two different mod- els were run, both based on the model of Fig. 8 but one with the ocean and another without the ocean. An example of the results is presented in Fig. 9, considering a site at about $50 \mathrm{~km}$ landward from the coast. As can be seen in the illustration, there is little difference in the response at short periods; beyond a given period (in this example, at about $10 \mathrm{~s}$ for apparent resistivity and $3 \mathrm{~s}$ for the phase), the curves for the models with and without an ocean differ significantly. In fact, the inclusion of the ocean splits the curves with the TM apparent resistivity curve rising and the TE apparent resistivity curve descending in relation to the response without the ocean. The corresponding reversed effect is observed in the phase.

In all tests that included an ocean, it was impossible to get both apparent resistivity curves rising together as shown in Fig. 3. A likely explanation for this discrepancy between experimental and theoretical results is the possible influence of regional features at large distances from the studied region. In the vicinity of the coastline, as is the case of this survey, MT soundings are normally biased by extra electric current perpendicular to the coastline and trapped in the upper mantle (Park et al., 1991). The main effect of this excess current is to shift to higher periods the point at which conductive deep layers would be sensed in apparent resistivity and phase curves. Unfortunately, absence of reliable induction arrows prevents examination of this hypothesis.

Similar calculations have been made considering stations located at different distances from the coast. The results of these tests are synthesized in Fig. 10. It shows the periods 


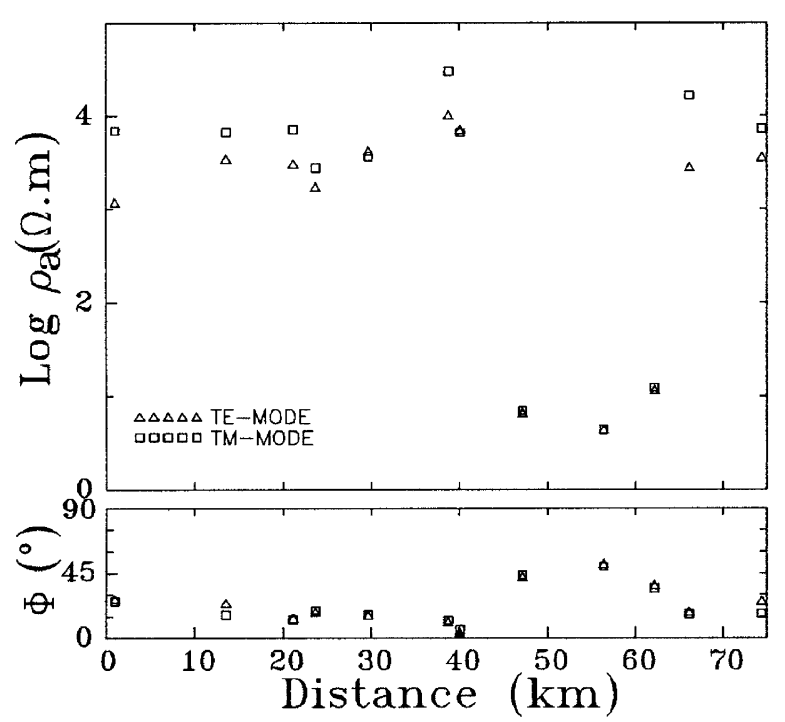

Fig. 7. TE- and TM-mode MT apparent resistivities and phases (translated to the first quadrant) from 12 stations at a period of $0.1 \mathrm{~s}$. Distance and site identification are the same as in Fig. 5. The sedimentary basin is located in the interval $45-65 \mathrm{~km}$.

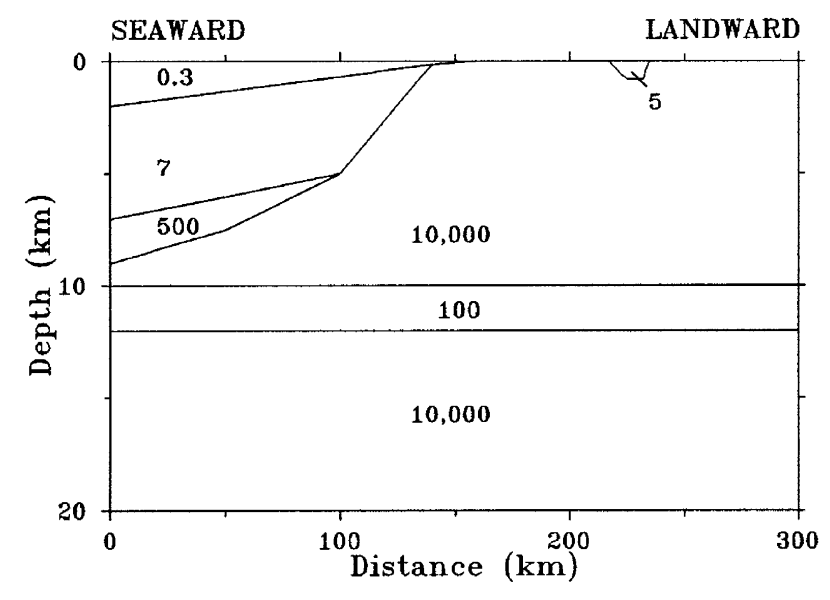

Fig. 8. Generalized 2D model used to test ocean effects in this study. Resistivity values are given in ohm.m.

at which the ocean would affect the apparent resistivity and phase in both modes of propagation of the electromagnetic waves. As already observed in Fig. 9, it can be seen that for a given sounding the coast effect always appears at shorter periods in the phase than in the apparent resistivity. Also, the TM-mode is much more affected than the TE-mode in soundings carried out very close to the coast. The latter result can be explained by considering that the TM-mode has a much higher resolution than the TE-mode to sense the electrical charges concentrated along the coast in the conductive sea. The higher resolution of the TM-mode disappears as we move away from the region where the strong lateral variation in conductivity occurs. In our case, the coast effect for both modes is seen to merge at approximately the same periods at distances around $50 \mathrm{~km}$ from the coast.

Additional tests were performed to investigate the effects on the data of the geometry of the coastline. A 3D forward

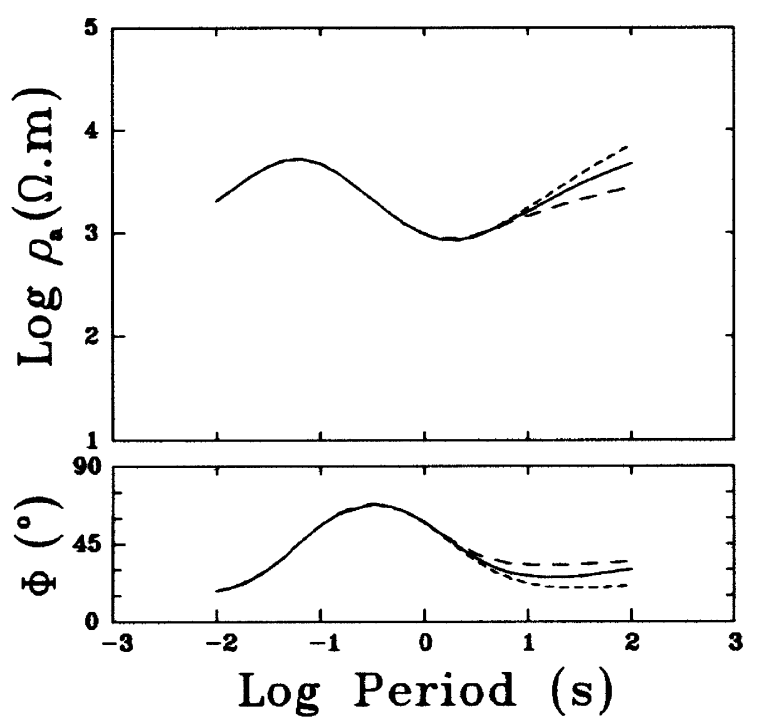

Fig. 9. Comparison of theoretical MT results generated by the 2D model of Fig. 8 with and without the ocean at a site $50 \mathrm{~km}$ landward from the coast. Continuous line is the response without the ocean, long-dashed line is the TE-mode response with the ocean and short-dashed line is the TM-mode response with the ocean. Upper graph is apparent resistivity and lower graph is impedance phase.

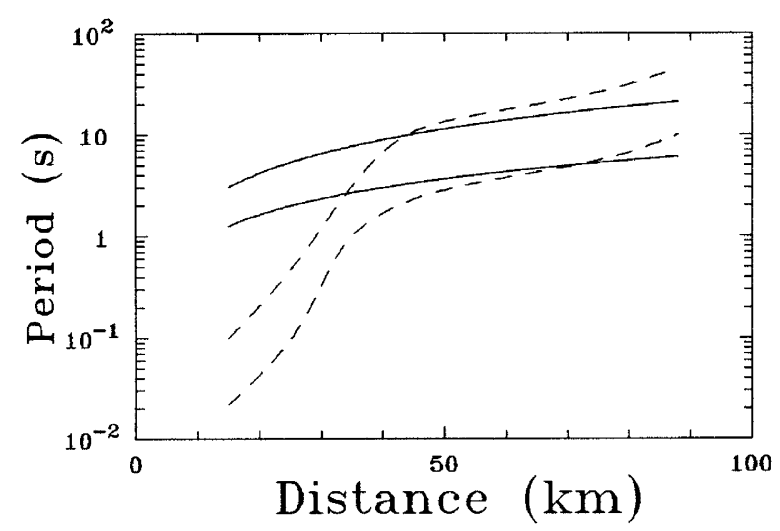

Fig. 10. Periods at which the coast effect would be theoretically sensed by the MT data as a function of the distance from the coast. Continuous lines are the TE-mode (upper curve is the effect on the apparent resistivity, lower curve is the effect on the phase) and dashed lines are the TM-mode (upper curve for apparent resistivity, lower curve for the phase).

modeling code was used (Mackie et al., 1993). It was observed however that such effects are negligible when compared to the ones described above. In conclusion, this exercise shows that the coast effect is extremely important on MT data acquired in this region of Brazil. Due to the large contrast in conductivities between the sea and the highly resistive rocks of the crust, the effects extend landwards over very large distances from the coast.

\section{Modelling and Resolution}

As previously explained, in the inversion we preferentially fit the phase information from all sites and the apparent resistivity data from the sites within the Taubate Basin that 


\section{Profile A-A' - 2D Inversion}

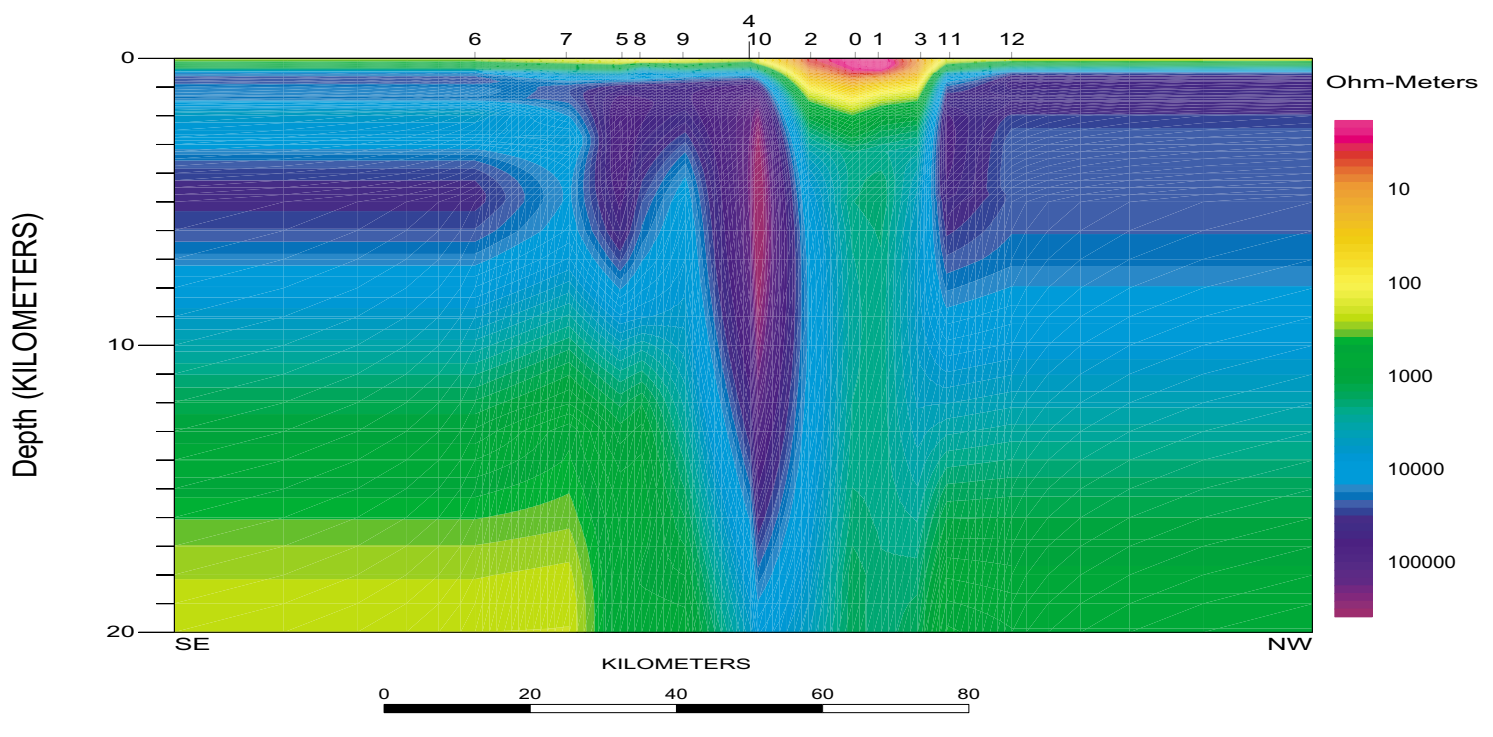

Fig. 11. Upper $20 \mathrm{~km}$ of the 2D model derived from RRI inversion for the TE and TM mode data of profile A-A'.

were considered to be little affected by static shifts. Accordingly, error tolerances for apparent resistivity from sites in resistive terrain were set to $25 \%$ (based on statistical studies of static shifts that show a typical standard error of $20 \%$ $25 \%$; Jones et al., 1993), whereas on the apparent resistivity of sites in the basin and on the phase for most of the sites an error floor of $3 \%$ was assumed (larger than the estimated error for more than half of the data and also accounting for effects of calibrations, geological and numerical noise on the impedance estimates; see Eisel and Egbert, 2001). At four sites where the decomposition model is inadequate at short periods (less than $0.01 \mathrm{~s}$ ), a larger error tolerance (25\%) was set on the phase within this interval. Also, to avoid effects due to industrial interference, we only used the data of both modes to $0.1 \mathrm{~s}$ for the Taubaté Basin sites. For the off-basin sites, the data were limited to periods at which the coast effect theoretically begins to be sensed by the MT data (given in Fig. 10).

The selected data were modelled two-dimensionally by using the RRI algorithm of Smith and Booker (1991), which recovers the smoothest model that fits the data. As we have excluded ocean effects from the data, it was not necessary to include the ocean as a fixed parameter in the start model and a uniform half space with resistivity of $100 \mathrm{ohm} . \mathrm{m}$ was chosen. The 2D model derived from joint TE and TM mode inversion is shown in Fig. 11 and a comparison between the calculated and observed phase responses is presented in Fig. 12 for each site. It can be seen that the model fits the phase data well (to better than $1.5^{\circ}$ on average), and the misfits between the data and the model responses are reasonably well distributed.

The inversion model was further tested by adding and removing some of its main features. All features were required to fit the data. In summary, the 2D model indicates that, excepting the Taubate Basin, the upper $10 \mathrm{~km}$ of the crust in the studied region is highly resistive, around 10,000 ohm.m. An isolated body with still higher resistiv- ity (around 100,000 ohm.m) is observed under sites 4 and 10, at the southeastern border of the Taubaté Basin. This structure is probably associated with one of the granitoids present in this region (see Fig. 2). The Taubate Basin is modelled with resistivities lower than 10 ohm.m and a maximum depth slightly less than $1 \mathrm{~km}$ (conductance larger than $100 \mathrm{~S}$ ). These results are in excellent agreement with the geological and geophysical information described previously (AMT, boreholes, DC vertical soundings, seismic and gravity surveys). A zone of enhanced conductivity is observed below the depth of $10 \mathrm{~km}$ to the SE and NW of the Taubate Basin. Due to the limited frequency range used in the inversion, there is very little resolution in the dataset to image the bottom of this conductor. Consequently, it is not possible to constrain its total conductance. The conductor is not imaged beneath the Taubate Basin, and this can possibly be attributed to the attenuation effects of the basin sediments and the restricted frequency range used in the inversion of the data.

Resolution analysis of this kind of model indicates that the thickness of the top layer and the maximum resistivity of the basal layer are well resolved parameters (see discussion in Jones, 1992). In this study, the data most sensitive to these parameters are apparent resistivity and phase values at periods around $3 \mathrm{~s}$ at the sites off the basin (see site 6 in Fig. 3 and off-basin phase data in Fig. 4). The 2D forward modelling of ocean effects suggests that only data from sites 11 and 12, positioned at the Serra da Mantiqueira plateau at distances farther than $60 \mathrm{~km}$ from the ocean, are reliable within such periods (see Fig. 10). The static shift values determined as part of the $2 \mathrm{D}$ inversion procedure were used to correct for the apparent resistivity at both sites and layered-Earth models were derived (Parker and Booker, 1996). It was observed that the top of the conductor at these sites occurs at a depth of $13.3 \pm 4.7 \mathrm{~km}$ and the maximum resistivity of the conductor is $500 \mathrm{ohm} . \mathrm{m}$.

Concerning the continuity of the conductor under the 

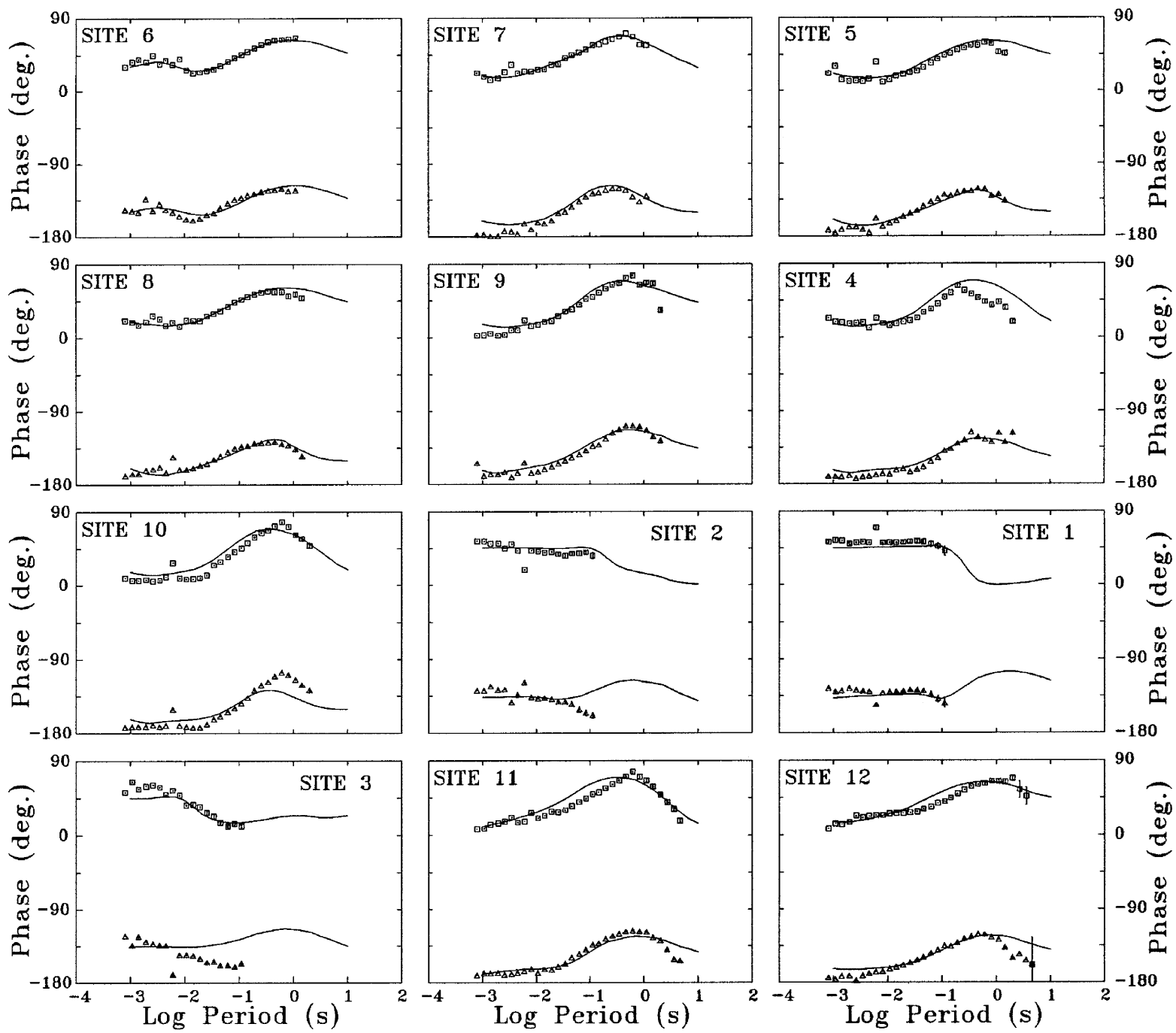

Fig. 12. The TE-mode (between 0 and $\left.90^{\circ}\right)$ and TM-mode $\left(-180\right.$ to $-90^{\circ}$ ) phases from all sites compared to the model responses (solid lines) obtained from the 2D model of Fig. 8, shown in sequential order from the SE to the NW of the profile A-A'.

Taubaté Basin, test modelling demonstrates that sensitivity to the continuation of the conductor below the basin is maximal in the TM responses at sites just outside the basin (sites 4 and 10, in the Serra do Mar plateau, and sites 11 and 12, in the Serra da Mantiqueira plateau). The reason for this is that the TM mode data are sensitive to the charges on the edges of any broken conductor. However, Bahr's analysis (Fig. 5) indicates that there is significant regional-scale 3D distortion in the band 1-10 s at sites 4 and 10 . Such effects can be attributted to the presence of a highly resistive granitoid at the southeastern border of the Taubaté Basin, which probably distorts the EM fields due to charges on its boundaries. As both effects are expected to be observed in the interval $1-10 \mathrm{~s}$, it is not possible to separate on the TM mode effects due to a broken conductor from $3 \mathrm{D}$ effects due to the presence of the granitoid. On the other hand, there is a considerable topographic variation in the region, especially in the northern part of the profile (sites 11 and 12). Studies on the effects of topography show that they are only significant for the TM mode (Jiracek, 1990). Test modelling for sites in the Serra da Mantiqueira plateau indicates that topographic effects appear again at the same period band (1-10 s) where the effects of the broken conductor would be sensed. Consequently, it is not possible to ascertain whether the conductor is continuous below the Taubate Basin with the available MT data.

\section{Discussion and Conclusions}

The interpretation of the MT data from our profile across the Taubate Basin shows a quite simple crustal structure with a sub-horizontal layering composed of a resistive upper $10 \mathrm{~km}$ of the crust, which hosts the localized highly conductive sediments of the Taubate Group, and a conductive crust below that depth. With the restrictions imposed on the available data set by industrial interferences on the basin sites and ocean effects on the off-basin sites, it is impossible to map any resistivity structure of the crust below this conductor. As a consequence, these data cannot contribute to the debate on the most adequate of the suggested tectonic models for the area. This is because the conductance of the middle and lower crust would be the major constraint to be imposed by the MT data in such discussion (see Padilha et al., 1991).

In comparison with the previous MT study at the Taubaté 
Basin, the main difference in the results is the detection of the the crustal conductive layer. This discrepancy can be easily explained if we consider that the first survey was carried out exclusively within the Taubaté Basin, affected by industrial noise and screening effects generated by the high conductance of the sedimentary package (larger than $100 \mathrm{~S}$ ). Conductive zones within the continental crust have been reported in many studies (see compilations by Shankland and Ander, 1983; Haak and Hutton, 1986; Hyndman and Shearer, 1989; Hyndman et al., 1993). Generically, the top of the layer seems to be located at depths greater than $10 \mathrm{~km}$, and its conductance is extremely varied apparently as a function of several parameters (tectonic characteristics, age of the structures, etc.). Among the different hypotheses already proposed to explain the origin of these layers, the most common explanations are interconnected brines and thin grain-boundary films. The debate is still open, especially by the opposing view of some petrologists in relation to the lack of evidence for the widespread occurrence of those factors (see, Yardley and Valley, 1997; Wannamaker, 2000; Yardley and Valley, 2000). Furthermore, the geodynamic processes responsible for such favorable conductive conditions are still to be elucidated.

Notwithstanding its cause and in spite of the conductance of these layers being extremely variable, and even very low in some shield regions, the inferred conductance of the layer is still much higher than expected of typical "dry" rocks from laboratory studies (less than $2 \mathrm{~S}$; Jones, 1992). Below long-stable geological terrains, as the region of this study, the current tendency among some geophysicists is to consider concentrations of solid-phase conductors, especially graphite, as the most likely candidates responsible for the middle crust increase in conductivity, although brines can also contribute (Wannamaker, 2000).

When comparing our results with those from other regions, it is important to consider the characteristics of our study area. The Precambrian crystalline complex of southeastern Brazil is of Archean age, but it was reworked by the Braziliano orogenic event and thermally and mechanically disturbed in Mesozoic-Cenozoic times. The literature on the conductance of middle to lower crust conductors indicates values from 2 to $40 \mathrm{~S}$ for the Archean structures and from 200 to $800 \mathrm{~S}$ for Proterozoic structures (Jones, 1992; Hyndman et al., 1993). On the other hand, the conductance of Archean areas extensively reworked during the Proterozoic is similar to values observed in the youngest areas (e.g., about $500 \mathrm{~S}$ in the north of Wisconsin; Dowling, 1970; Goodwin, 1996). Our data do not allow any conclusion about the total conductance of the conductive layer in the crust. However, the MT data for the profile $300 \mathrm{~km}$ to the NE on the same geological province of the present study were interpreted by Figueiredo (1997) as indicating the presence of a deep conductor at the same depth $(10 \mathrm{~km})$, with total conductance estimated to be about $100 \mathrm{~S}$. However, such interpretation must be taken cautiously because ocean effects were not included in the model.

Industrial interferences and mainly ocean effects have impoverished the resolution of the MT data of this study. Possible alternatives to minimize the coast effect include the numerical resolution of the problem (see Monteiro Santos et $a l ., 2001)$ or the inclusion of the sea as a fixed parameter in the bidimensional modelling of the data. In both cases however we face the difficulty of getting a reasonable model for the distribution of conductivities in the oceanic lithosphere, an information presently not available for this region of the South Atlantic. Other studies in the same area and in other parts of the Brazilian shield, possibly involving other geophysical methods, will be necessary to obtain more relevant information about the electrical structure of the lower crust and upper mantle.

Acknowledgments. This study was supported by research grants from FAPESP (93/0652-2 and 95/0687-4) and fellowships from CNPq (350683/94-8 and 351398/94-5) and FAPESP (96/020968 ). The manuscript was considerably improved by constructive suggestions made by Alan Jones, Hiroshi Munekane, and Yasuo Ogawa.

\section{References}

Almeida, F. F. M., The system of continental rifts bordering the Santos Basin, Brazil, An. Acad. Bras. Ciênc., 48, 15-26, 1976.

Asmus, H. E. and A. L. Ferrari, Hipótese sobre a causa do tectonismo cenozóico na região sudeste do Brasil, in Aspectos Estruturais da Margem Continental Leste e Sudeste do Brasil, Sér. Proj. REMAC 4, pp. 75-88, CENPES/PETROBRÁS, Rio de Janeiro, 1978.

Bahr, K., Geological noise in magnetotelluric data: A classification of distortion types, Phys. Earth Planet. Inter., 66, 24-38, 1991.

Berrocal, J., M. Assumpção, R. Antezana, C. M. Dias Neto, R. Ortega, H. França, and J. A. V. Veloso, Sismicidade do Brasil, 320 pp., IAGUSP/CNEN, São Paulo, 1984.

Boerner, D. E., J. A. Wright, G. J. Thurlow, and L. E. Reed, Tensor CSAMT studies at the Buchans Mine in central Newfoundland, Geophysics, 58, 12-19, 1993.

Brito, P. M. A., Sondagens magnetotelúricas transversais à Bacia de Taubaté, MSc. Thesis, 106 pp., INPE/MCT, São José dos Campos, 1998.

DAEE (Departamento de Águas e Energia Elétrica do Estado de São Paulo), Estudo de águas subterrâneas: Região administrativa 3 - São José dos Campos, Governo do Estado de São Paulo, São Paulo, Vol. 4, 19 pp., 1977.

Deckart, K., G. Feraud, L. S. Marques, and H. Bertrand, New time constraints on dyke swarms related to the Parana-Etendeka magmatic province, and subsequent South Atlantic opening, southeastern Brazil, $J$. Volcanol. Geoth. Res., 80, 67-83, 1998.

Dowling, F. L., Magnetotelluric measurements across the Wisconsin Arch, J. Geophys. Res., 75, 2683-2698, 1970.

Egbert, G. D. and J. R. Booker, Robust estimation of geomagnetic transfer functions, Geophys. J. R. Astron. Soc., 87, 173-194, 1986.

Eisel, M. and G. D. Egbert, On the stability of magnetotelluric transfer function estimates and the reliability of their variances, Geophys. J. Int., 144, 65-82, 2001

Figueiredo, I., Investigação magnetotelúrica nas serras do sudeste brasileiro (RJ/MG): Uma proposta de modelo crustal, Ph.D. Thesis, 163 pp., Observatório Nacional/CNPq, Rio de Janeiro, 1997.

Goodwin, A. M., Principles of Precambrian Geology, 327 pp., Academic Press, San Diego, 1996.

Groom, R. W. and R. C. Bailey, Decomposition of magnetotelluric impedance tensors in the presence of local three-dimensional galvanic distortion, J. Geophys. Res., 94, 1913-1925, 1989.

Haak, V. and V. R. S. Hutton, Electrical resistivity in continental lower crust, in The Nature of the Lower Continetal Crust, edited by J. B. Dawson, D. A. Carswell, J. Hall, and K. D. Wedepohl, Spec. Publ. Geol. Soc. London, 24, 35-49, 1986.

Hasui, Y., A. F. Gimenez, and M. S. Melo, Sobre as bacias tafrogênicas continentais do sudeste brasileiro, in Ann. 30th Congresso Brasileiro de Geologia, 1, 382-391, 1978.

Hyndman, R. D. and P. M. Shearer, Water in the lower continental crust: modeling magnetotelluric and seismic reflection studies, Geophys. J. Int., 98, 343-365, 1989.

Hyndman, R. D., L. L. Vanyan, G. Marquis, and L. K. Law, The origin of electrically conductive lower continental crust: saline water or graphite?, Phys. Earth Planet. Inter, 81, 325-344, 1993.

Jiracek, G. R., Near-surface and topographic distortions in electromagnetic 
induction, Surv. Geophys., 11, 163-203, 1990.

Jones, A. G., Static shift of magnetotelluric data and its removal in a sedimentary basin environment, Geophysics, 53, 967-978, 1988.

Jones, A. G., Electrical conductivity of the continental lower crust, in Continental Lower Crust, edited by D. M. Fountain, R. J. Arculus, and R. W. Kay, pp. 81-143, Elsevier, Amsterdam, 1992.

Jones, A. G., J. A. Craven, G. W. McNeice, I. J. Ferguson, T. Boyce, C. Farquarson, and R. G. Ellis, North American Central Plains conductivity anomaly within the Trans-Hudson orogen in northern Saskatchewan, Canada, Geology, 21, 1027-1030, 1993.

Macedo, J. M., Evolução tectônica da Bacia de Santos e áreas continentais adjacentes, Bol. Geoc. Petrobrás, 3, 159-173, 1989.

Mackie, R. L., T. R. Madden, and P. E. Wannamaker, Three-dimensional magnetotelluric modeling using difference equations - Theory and comparisons to integral equation solutions, Geophysics, 58, 215-226, 1993.

Marques, A., Evolução tectono-sedimentar e perspectivas exploratórias da Bacia de Taubaté, São Paulo, Brasil, Bol. Geoc. Petrobrás, 4, 253-262, 1990.

Monteiro Santos, F. A., M. Nolasco, E. P. Almeida, J. Pous, and L. A. Mendes Vitor, Coast effects on magnetic and magnetotelluric transfer functions and their correction: application to MT soundings carried out in SW Iberia, Earth Planet. Sci. Lett., 186, 283-295, 2001.

Padilha, A. L. and Í. Vitorello, Investigações geoelétricas nas bacias de Taubaté, Volta Redonda e Resende, in Expanded Abstracts of the 37th Congresso Brasileiro de Geologia, 2, 403-404, 1992.

Padilha, A. L., N. B. Trivedi, Í. Vitorello, and J. M. Da Costa, Geophysical constraints on tectonic models of the Taubate Basin, southeastern Brazil, Tectonophys., 196, 157-273, 1991.

Park, S. K., G. P. Biasi, R. L. Mackie, and T. R. Madden, Magnetotelluric evidence for crustal suture zones bounding the southern Great Valley, California, J. Geophys. Res., 96, 353-376, 1991.

Parker, R. L. and J. B. Booker, Optimal one-dimensional inversion and bounding of magnetotelluric apparent resistivity and phase measurements, Phys. Earth Planet. Inter., 98, 269-282, 1996.

Pereira, M. J. and F. J. Feijó, Bacia de Santos, Bol. Geoc. Petrobrás, 8, 219-234, 1994.

Qian, W. and L. B. Pedersen, Industrial interference magnetotellurics: An example from the Tangshan area, China, Geophysics, 56, 265-273, 1991.

RADAMBRASIL, Levantamento dos recursos minerais (Mapa geológico
1:1,000,000), Brasília, 1983.

Ramos, R. G. N., A. R. Saad, V. L. Galli, and V. A. Campanha, Modelo gravimétrico da compartimentação estrutural da Bacia de Taubaté (Jacareí-Aparecida do Norte), in Rel. DGRM/IPT 10-R28732, 22 pp, IPT, São Paulo, 1990.

Riccomini, C., O rifte continental do sudeste do Brasil, Ph.D. Thesis, 304 pp., Univ. São Paulo, São Paulo, 1989.

Sadowski, G. R. and C. M. Dias Neto, O lineamento sismotectônico de Cabo Frio, Rev. Bras. Geoc., 11, 209-212, 1981.

Shankland, T. J. and M. E. Ander, Electrical conductivity, temperature, and fluids in the lower crust, J. Geophys. Res., 88, 9475-9484, 1983.

Smith, J. T. and J. R. Booker, Rapid inversion of two- and three-dimensional magnetotelluric data, J. Geophys. Res., 96, 3905-3922, 1991.

Swift, C. M., A magnetotelluric investigation of an electrical conductivity anomaly in the South-Western United States, Unpubl. Ph.D. thesis, Dept. Geology Geophys., Mass. Inst. Technol., Cambridge, 1967.

Thompson, R. N., S. A. Gibson, J. G. Mitchell, A. P. Dickin, O. H. Leonardos, J. A. Brod, and J. C. Greenwood, Migrating Cretaceous-Eocene magmatism in the Serra do Mar alkaline province, SE Brazil: melts from the deflected Trindade mantle plume?, J. Petrol., 39, 1493-1526, 1998.

Wannamaker, P. E., Comment on "The petrologic case for a dry lower crust" by B. W. D. Yardley and J. W. Valley, J. Geophys. Res., 105, 6057-6064, 2000 .

Wannamaker, P. E., J. A. Stodt, and L. Rijo, A stable finite element solution for two-dimensional magnetotelluric modelling, Geophys. J. R. Astron. Soc., 88, 277-296, 1987.

Wu, N., J. R. Booker, and J. T. Smith, Rapid two-dimensional inversion of COPROD2 data, J. Geomag. Geoelectr., 45, 1073-1087, 1993.

Yardley, B. W. D. and J. W. Valley, The petrologic case for a dry lower crust, J. Geophys. Res., 102, 12173-12185, 1997.

Yardley, B. W. D. and J. W. Valley, Reply to P.E. Wannamaker's comments, J. Geophys. Res., 105, 6065-6068, 2000.

Zalán, P. V., A tectônica transcorrente na exploração de petróleo: Uma revisão, Rev. Bras. Geoc., 16, 245-257, 1986. A. L. Padilha (e-mail: padilha@dge.inpe.br), Í. Vitorello, and P. M. A. 